\title{
The Causes and Effects of China's Double Surplus of Balance of Payments-Based on the Study of FDI Inflow in 1993-2012
}

\author{
Botao Zhang \\ Jinan University, Guangzhou, China \\ Email: 601606825@qq.com
}

How to cite this paper: Zhang, B.T. (2017) The Causes and Effects of China's Double Surplus of Balance of Payments-Based on the Study of FDI Inflow in 1993-2012. Open Journal of Social Sciences, 5, 1-15. https://doi.org/10.4236/jss.2017.55001

Received: March 13, 2017

Accepted: May 6, 2017

Published: May 9, 2017

Copyright $\odot 2017$ by author and Scientific Research Publishing Inc. This work is licensed under the Creative Commons Attribution International License (CC BY 4.0).

http://creativecommons.org/licenses/by/4.0/

\section{(c) (i) Open Access}

\begin{abstract}
Double surplus in balance of payments is a surplus of both current account and capital and financial account during the same period. In recent years, substantial scholars have made a thorough study about this topic, but there still exists a big gap between theory and real economy. The existing literatures pay little attention to the current China's surplus structure, especially from the perspective of FDI inflows. This paper examines the general situation of China's double surplus in international balance of payments and analyzes its causes. Empirical research on the representative factors that influence the China's balance of payments suggests foreign direct investment de facto contributes a large portion to the overall surplus in the balance of payments. It accordingly makes further research on the role of FDI presenting how FDI affects double surplus of China's balance of payments and its influences on China's economy. This paper is organized as follows: Chapter 1 is an introduction; Chapter 2 is general introduction of China's balance of payments; Chapter 3 is the empirical analysis; Chapter 4 is the mechanism analysis of FDI; Chapter 5 is domestic influence of China's international balance of payments surplus; Chapter 6 is about policy recommendations for China's double surplus.
\end{abstract}

\section{Keywords}

Structure of Balance of Payments, Double Surplus, FDI

\section{Introduction}

The developing country usually has a trade deficit in current accounts and surplus in capital and financial accounts. But China holds double surplus in both two types of international balance of payments, which are not beneficial to both internal and external economy. Since the development of reform and opening 
up, FDI has shown great influence on China's international balance of payments, mainly in current accounts trade and direct investment of capital accounts. Scholars from different countries have studied the influence FDI brought to developing countries early on. Baran (1973) [1] first put forward that foreign money comes in for the sake of extracting surplus value of the home country. $\mathrm{He}$ believed the outflow of profit and investment revenue will aggravate the international balance of payments of the home country (usually developing countries) and make it more dependent on foreign trade. During the same period, Samuelson and Hass (1979) [2] held that there are four stages for a country to realize equilibrium in balance of payments, namely new debtor country, mature debtor country, new creditor country, and finally mature creditor country with corresponding investment structure. At the end of $20^{\text {th }}$ century, Dooley (1994) [3] found a higher ratio of FDI will suggest a higher fluctuation in financial crises. Then Reis (2001) [4] improved Baran's idea from the perspective of economic welfare of the home country. He studied FDI in static and dynamic cases separately and showed both them can make "creative destruction", which will lead to the profit gained from FDI flow from home country to the host one, namely from developed country to developing ones, thereby destroying the latter's international balance of payments. Woodward (2003) further found the inflow of FDI and other forms of money is to gain profit in essence. As the profit gained from them flowing out, it is difficult for the home country to maintain equilibrium in the balance of international payments, and there may even lay the possible consequence of financial crises.

Later on China's scholars began to research how FDI influences China's international balance of payments at the beginning of $21^{\text {st }}$ century. Yang (2003) [5] discussed the influencing factors of the balance of payments by designing an econometric model and predicted capital accounts may turn into deficit soon. Through applying L-S model, Liu (2005) [6] analyzed the relationship between FDI inflow and international balance of payments and found FDI inflow may bring greater pressure to the home country with the increase of profit remittance ratio and the decline of the reinvestment ratio. Yu (2006) [7] explored various types of FDI and their influence on China's balance of payments. He showed a large portion of the double surplus is the result of the long term policy of attracting foreign investment.

Besides, Liu (2001) [8] made a synthetic analysis from both static and dynamic effects of the influence of FDI inflow on the balance of payments of home and host country, revealing FDI is favorable to host country and unfavorable to the other. He (2004) tried to explore the reason for the double surplus existing continuously for many years from perspective of foreign policy, development disparity and monetary policy. Mao and D (2005) drew from their study that investment profit remittance incurred by FDI may cause crises in international balance of payments. After that, Zou, X. (2006) [9] conducted empirical tests of significance and cointergration using the data of China's balance of payments during the period of 1982-2003, eventually finding there exists a significant posi- 
tive correlation between foreign money inflow and China's double surplus. And he initially proposed the aim of adjusting the structure model of China's balance of payments and the orientation of policy making.

In view of the existing literature, it seems that most well-disciplined and databased studies only focus on general situation of developing countries, less attention has not been paid to the situation in China. Moreover, the data utilizing by scholars like Zou, X. has not been updated for a decade, during which radical changes have taken place in China. Therefore, this paper is to make full use of the international balance sheet of the late two decades and try to explain the reason, changes and solution for the double surplus in China.

\section{General Introduction of China's Balance of Payments}

Double surplus in international balance of payments refers to the continuous and large scale surplus of current accounts capital and financial accounts in the balance sheet. Theoretically, above two types of accounts are complementary and they are not in surplus during the same period. But China is an exception. For current accounts, surplus usually appears at the result of more export than import; for capital and financial accounts, it is caused by more FDI inflow than domestic capital outflow. As discussed above, current accounts are complementary to capital \& financial accounts due to the digestion of domestic wealth within domestic market, which is an important factor for the export of commodity and capital. If the country's digestive capacity is insufficient, capital will seek a large consumer demand market and form trade and capital expansion, that is, the surplus of current account and the deficit of capital and financial account, like the situation in Japan. If the country's digestive capacity is higher that productivity, foreign trade and capital will join in, accordingly producing the deficit of current account and the surplus of capital and financial account, like in United States. China has realized the paradoxical double surplus for most of the past twenty years, which attributes to both internal factors (government intervention, people's savings habits, etc.) and external factors (large influx of capital). However, the latter have great uncertainty. The withdrawal of FDI may bring a heavy blow to China's international balance of payments at any time. Hence, it's worth studying the causes of China's international balance of payments mainly considering external factors.

Based on traditional development economics, the balance of payments structure in developing countries should be the current account deficit and capital and financial account surplus because domestic production cannot satisfy consumer demand. But China's "surplus + surplus" pattern existing for past two decades deviates from the traditional theory and other developing countries' reality, and it should be regarded as the external performance of domestic economy imbalances. At the same time, in recent years, China has been the world's largest developing countries to attract FDI for over ten years, its capital scale always list top position in the world. This fact and the blank of existing study motivate me to make in-depth analysis of the impact and trend of FDI on the bal- 
ance of payments.

\section{The Empirical Analysis}

The double surplus situation of China's international balance of payments has produced many negative effects on China's economy, and in the context of global economic imbalances, these negative effects also on the rise. So it's meaning to analyze the causes of the double surplus and take measures to reduce the negative influences. In recent years, FDI has continuously flowed into China as the main source of capital surplus, how does FDI affects double surplus? The following will verify their correlation by the empirical framework.

\subsection{Research Methods and Analysis}

In this paper, I use the method of unit root test, cointegration test and Granger causality test together, to divide the factors that affect the gross spread (DS) of balance of payments into domestic economic policy factors and foreign investment factors. Domestic economic policy factors include domestic Gross Domestic Product (GDP) and China's Tariff (TAX), whereas foreign direct investment (FDI) denotes foreign investment factors. In this paper, the samples are annual data which range from 1993 to 2012. Most of the data comes from the China National Bureau of Statistics, State Administration of Foreign Exchange and the Chinese Ministry of Finance's official website. Considering the trend of time series data, natural logarithm of these data is taken to eliminate the heteroscedasticity and linearize the trend, which does not change the cointegration relationship between variables. The variables DS, GDP, FDI, TAX were taken as natural logarithm, marked as LnDS, LnGDP, LnFDI, LnTAX respectively. EViews7.2 and Stata 13.1 are applied to finish the following statistical analysis.

\subsection{Correlation Analysis}

As shown in Table 1, both correlation coefficients of LnDS and LnFDI, LnGDP and LnTAX are all exceed 0.8 , and the positive correlation is significant, verifying the strong correlation between the variables. From statistical point of view, it seems necessary to establish multiple linear regression models. Thus, time series analysis of the following variables is done at first.

\subsection{Time Series Analysis}

\subsubsection{Unit Root Test}

This paper will use the Augmented Dickey-Fuller test (ADF) tests. As described in Table 2 below, the absolute value of the ADF statistic of each variable is less than the critical value at the significance level of $10 \%$, it indicates the original sequence accepts the original hypothesis at $10 \%$ significant level, that is, the original sequence is non-stationary. And the first order difference sequence DLnDS and DLnFDI are significant at $1 \%$ level, DLn TAX is significant at $5 \%$ level, DLnGDP is significant at $10 \%$ significant level, all show that the first order differential sequence of these variables are stationary. Therefore, LnDS, LnFDI, 
Table 1. Correlation coefficient between variables.

\begin{tabular}{ccccc}
\hline & LNDS & LNFDI & LNGDP & LNTAX \\
\hline LNDS & 1.000000 & 0.914302 & 0.876352 & 0.818814 \\
LNFDI & 0.914302 & 1.000000 & 0.978452 & 0.918936 \\
LNGDP & 0.876352 & 0.978452 & 1.000000 & 0.966218 \\
LNTAX & 0.818814 & 0.918936 & 0.966218 & 1.000000 \\
\hline
\end{tabular}

Table 2. Result of unit root test.

\begin{tabular}{ccccccc}
\hline variant & $\begin{array}{c}\text { Test Type } \\
(\mathrm{c}, \mathrm{t}, \mathrm{p})\end{array}$ & ADF statistic & $\begin{array}{c}1 \% \text { critical } \\
\text { value }\end{array}$ & $\begin{array}{c}5 \% \text { critical } \\
\text { value }\end{array}$ & $\begin{array}{c}10 \% \text { critical } \\
\text { value }\end{array}$ & Result \\
\hline LnDS & $(\mathrm{c}, \mathrm{t}, 4)$ & -2.29 & -3.83 & -3.03 & -2.66 & Non-stationary \\
LnFDI & $(\mathrm{c}, \mathrm{t}, 4)$ & -1.118 & -3.83 & -3.03 & -2.66 & Non-stationary \\
LnGDP & $(\mathrm{c}, \mathrm{t}, 4)$ & 1.05 & -3.96 & -3.08 & -2.68 & Non-stationary \\
LnTAX & $(\mathrm{c}, \mathrm{t}, 4)$ & -0.22 & -3.83 & -3.03 & -2.66 & Non-stationary \\
D LnDS & $(\mathrm{c}, 0,4)$ & $-4.32^{*}$ & -3.86 & -3.04 & -2.66 & Stationary \\
D LnFDI & $(\mathrm{c}, 0,4)$ & $-5.24^{*}$ & -3.86 & -3.04 & -2.66 & Stationary \\
D LnGDP & $(\mathrm{c}, 0,4)$ & $-2.76^{* * *}$ & -4.00 & -3.01 & -2.69 & Stationary \\
D LnTAX & $(\mathrm{c}, 0,4)$ & $-3.49^{* *}$ & -3.92 & -3.07 & -2.67 & Stationary \\
\hline
\end{tabular}

Note: $(c, t, p)$ represent the intercept term, time trend term and lag intervals in the unit root test model, respectively. The superscript ${ }^{*},{ }^{* *},{ }^{* *}$ represent the significance level of $1 \%, 5 \%$ and $10 \%$, respectively. In addition, optimal lag intervals are selected by EViews7.2 according to minimum AIC principle.

LnGDP, LnTAX are first-order integrated sequences, namely I (1), which meets the premise of co-integration test and the variables can be checked by co-integration test.

\subsubsection{Cointegration Test}

This paper uses the Max-Eigen method in JJ test to examine LnDS, LnFDI, LnGDP and LnTAX. The variables have a certain trend, so the cointegration equation should include the intercept term. In Table 3, Johanson covariance test results show that LnDS, LnFDI, LnGDP and LnTAX have a cointegration relationship at the $5 \%$ level. That is to say, total foreign direct investment (FDI), gross domestic product (GDP) and tariff level (TAX), all reflect a long-term stable relationship with double surplus of the balance of payments (DS).

\subsubsection{Granger Causality Test}

The Cointegration Test shows a long-term stable relationship among the total double surplus of the balance of payments (DS) with foreign direct investment (FDI), gross domestic product (GDP) and tariff level (TAX). Then it should be conducted to know the causality relation. Making Granger causality text on LnDS, LnFDI, LnGDP, LnTAX, and obtaining the results as follows:

Table 4 shows that, at $5 \%$ significant level, foreign direct investment and tariffs are the Granger cause for the double surplus of China's balance of payments, whereas there is a reciprocal causation between GDP and double surplus 
Table 3. Cointegration Test Results of DS, FDI, GDP and TAX.

\begin{tabular}{|c|c|c|c|c|}
\hline Hypothesized & \multirow{2}{*}{ Eigenvalue } & Trace & 0.05 & \multirow{2}{*}{ Prob. ${ }^{* *}$} \\
\hline No. of CE(s) & & Statistic & Critical Value & \\
\hline None* & 0.9225 & 83.3306 & 63.8761 & 0.0005 \\
\hline At most 1 & 0.6185 & 37.3048 & 42.9152 & 0.1626 \\
\hline At most 2 & 0.4722 & 19.9577 & 25.8721 & 0.2281 \\
\hline At most 3 & 0.3748 & 8.4553 & 12.5180 & 0.2167 \\
\hline
\end{tabular}

Note: ${ }^{\star}$ denotes the hypothesis is rejected at $5 \%$ significance level.

Table 4. Granger Causality Test Results of DS, FDI, GDP and TAX.

\begin{tabular}{lccc}
\hline Original Hypothesis & $\begin{array}{c}\text { Lag Intervals for } \\
\text { Endogenous }\end{array}$ & F statistic & $\begin{array}{c}\text { Probability Whether Reject the } \\
\text { Original Hypothesis }\end{array}$ \\
\hline $\begin{array}{c}\text { LnFDI is not the Granger } \\
\text { causality of LnDS }\end{array}$ & 2 & 4.116 & 0.041 reject \\
$\begin{array}{c}\text { LnFDI is not the Granger } \\
\text { causality of LnDS }\end{array}$ & 2 & 1.977 & 0.178 accept \\
$\begin{array}{c}\text { LnFDI is not the Granger } \\
\text { causality of LnDS }\end{array}$ & 2 & 7.417 & 0.007 reject \\
$\begin{array}{c}\text { LnFDI is not the Granger } \\
\text { causality of LnDS }\end{array}$ & 2 & 8.928 & 0.004 reject \\
$\begin{array}{c}\text { LnFDI is not the Granger } \\
\text { causality of LnDS }\end{array}$ & 2 & 4.381 & 0.035 reject \\
LnFDI is not the Granger \\
causality of LnDS
\end{tabular}

of balance of payments. Thus, a multiple linear regression model can be established to study its long-term equilibrium relationship. The results are obtained by Stata 13.1.

$$
\operatorname{LnDS}=-0.88+2.31 \mathrm{LnFDI}-0.98 \mathrm{LnGDP}+0.22 \mathrm{LnTAX}
$$

As can be seen from the above model, each additional 1 unit of foreign direct investment or tariffs can bring 2.31 units of double surplus or 0.22 units of the double surplus. Once GDP reach a certain stock amount, more and more domestic wealth will seek foreign investment channels to digest, thus leading to the result of deficit in current account or financial and investment account; on the other hand, it also causes the double surplus of the balance of payments from the opposite direction. In addition, they are reciprocal causation, namely, as China's double surplus of the international balance of payments expanding, domestic wealth may also shrink, it's worthy of attention. Furthermore, the above analysis implies that foreign direct investment will give rise to more significant increase in the double surplus than other factors. In a word, it is easy to conclude that foreign direct investment has a great positive effect on China's double surplus of international balance of payments. Through empirical research, FDI is worth to as an important factor to study the double surplus of China's international balance of payments, and the following is to further study the mechanism of FDI's 
influences on double surplus.

\section{The Mechanism Analysis of FDI}

\subsection{The Path Analysis of FDI Affecting Current Account Surplus}

China's current account surplus is the largest in number and mainly comes from the trade in goods dominated by FDI, so it is FDI that lead to China's current account surplus. On the one hand, FDI can increase the surplus of the current account by using the host country's resources to increase the trade surplus. On the other hand, FDI can remit the profits from the host country to the home country to promote the host country's current account deficit, so that the income account continues to fail in making ends meet. However, by observing the changes of FDI in China Statistical Yearbook, it can be found that the profits generated by a large number of FDI remain in China as reinvestment, and some investment is left in China because of the expected appreciation of China's exchange rate. Therefore, in recent years, the impact of FDI on the current account is reflected in the surplus. FDI into China has three types: market-oriented, export-oriented and technology-oriented. China lacks the third type of FDI, which focuses on the introduction of foreign advanced technology. Most of the FDI in real life is the first and the second type, especially the first one that is used to produce re-exports from China's low-cost raw materials and labor costs. According to the balance of payments, the impact of FDI on China's current account is mainly in the goods account and the income account. Most scholars believe that the inflow of FDI leads to the development of China's foreign trade, and the second type of FDI, which is dominated by export-oriented, increases the surplus of China's current account. Through the empirical analysis, it can also find that FDI has played a great role in promoting the surplus of the current account in the past two decades. The influence paths of FDI on the current account can be divided into direct and indirect effect. Direct effect refer to the impact of foreign-invested enterprises' trade behaviors on total import and export volume and structure of the host country, which is mainly reflected in the first and second types of FDI. Indirect effect refers to changes in the volume of imports and exports of local enterprises in the host country as a result of the inflow of foreign direct investment, which is mainly reflected in the third type of FDI. The direct effect of FDI on current account is mainly of the first and second types of FDI, namely, market-oriented foreign direct investment and export-oriented foreign direct investment. Export-oriented foreign direct investment is to use China's cheap labor and raw materials and other resources. The home country's advanced technology and strong capital applied to the host country reduces the cost of export goods in the international market, which plays a comparative advantage to enhance products in the international market by increasing the market share and thus contributing to the development of the export of the host country. And market-oriented foreign direct investment is to bypass the host country's trade barriers, and go directly into the host market. Market-oriented investment in the initial production period will bring import of 
machinery equipment and spare parts that go against the host country's trade surplus. By the time the invested enterprises get into the production period, the products produced will replace the import and lead to a sharp increase in surplus induced by FDI, thus forming a "J-curve" shown in Figure 1, marketoriented FDI will eventually reduce the import and increase trade surplus.

Whether the direct effect of foreign direct investment can benefit continuously the surplus on the balance of payments relies on the comparison of net export and profit remittance. If the former exceeds the latter, the foreign investment will have a positive effect on China's international balance of payments which is the situation in China at present. In reverse, if the net export is less than the profit remittance, it will generate deficit on China's international balance of payments and this effect may gradually enlarge in the future. In general, the export-oriented foreign enterprises tend to export and have a large effect on the surplus of balance of payments; whereas market-oriented foreign enterprises tend to make domestic sales and can replace the host country's import behavior, which will also indirectly enlarge surplus of balance of payment in the long term. The indirect effect of foreign direct investment is mainly reflected in the third type of FDI. Chinese enterprises generally invest abroad to learn advanced technology, but few foreign investors invest in China for the same sake. So the indirect effect of FDI in China is lacking. But in the long run, China will attract this type of FDI to indirectly affect Chinese enterprises, which is mainly reflected in the following aspects. First, the inflow of foreign direct investment brings China's enterprises into the international division system, promoting them to participate in the production, sales and competition in international markets.

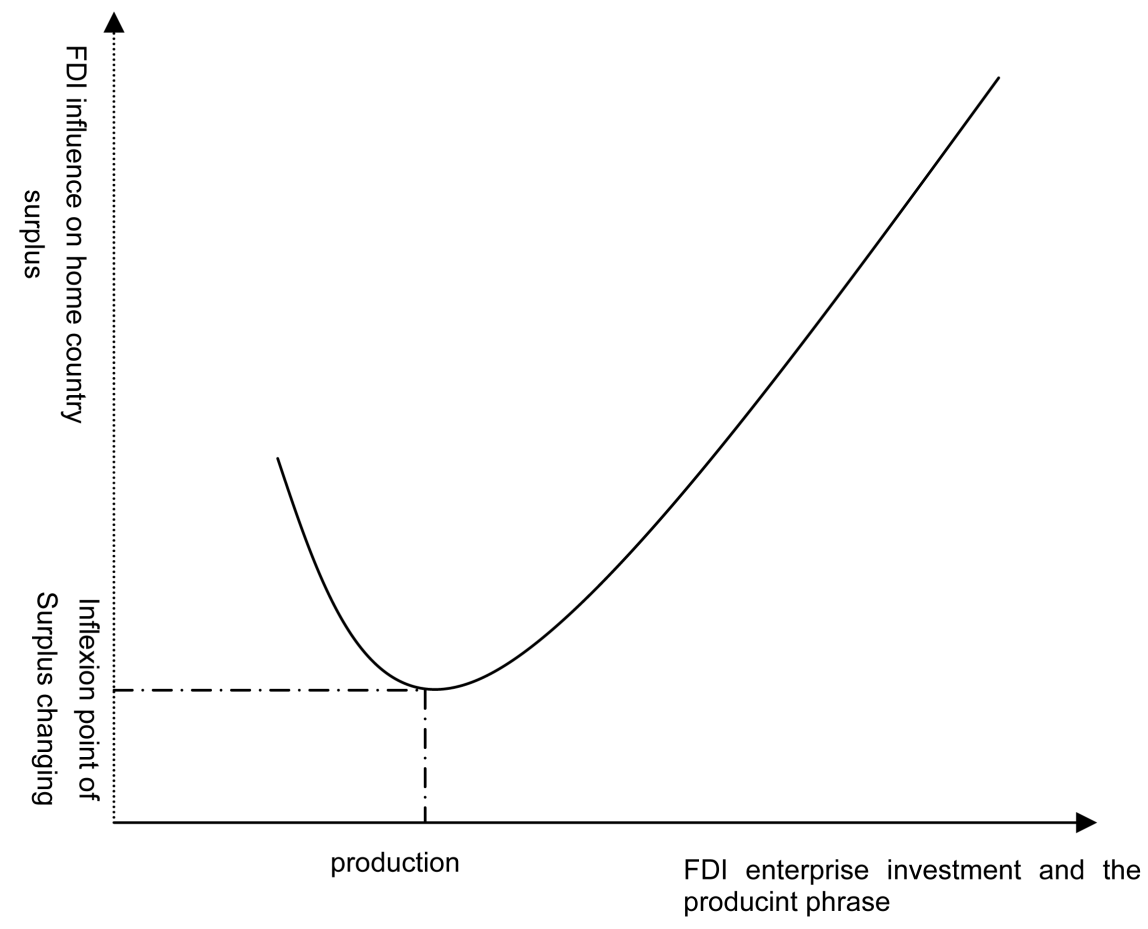

Figure 1. J-curve. 
Second, the technology spillover effect and the flow of labor force of foreignfunded enterprises can bring advanced technical and management experience to local enterprises, making local enterprises export technology-intensive products. Thirdly, foreign direct investments enhance the competition intensity in domestic market, forcing the domestic enterprises adopt advanced technology and management experience in order to expand exports and increase the surplus.

In sum, the host country's trade surplus to a great extent attributes to foreign direct investment. Specifically, foreign direct investment invested in the primary industry mostly belong to export-oriented enterprise, its direct effect is obvious; investment in the secondary industry is a little complex, but the indirect effect that can promote export development of local enterprises is relatively obvious; because the service products cannot be exported, foreign investment in the tertiary industry is difficult to get direct profit. Though its direct effect is quite limited, the demonstration effect, as a certain indirect effect, can improve the export of local enterprise.

\subsection{The Impact of FDI Inflows on the Surplus of Capital and Financial Items}

The impact of FDI on China's capital and financial surplus is straightforward and it can be found by calculating the contribution rate of FDI, which is the ratio of net inflow of foreign direct investment and surplus of capital and finance accounts. Based on the data from China Statistical Yearbook, the contribution rate of FDI to China's capital account surplus from 1993 to 2012 is presented in Figure 2.

It can be seen from Figure 2, except the data of China's capital and financial deficit in 1998, the contribution rates of FDI to China's capital and financial surplus are all positive in remaining 19 years, twelve of which are more than $100 \%$ and two of which even above $1000 \%$. On average, the contribution rate of FDI to China's capital and financial surplus during $1993-2010$ is $130.97 \%$. Take capital and financial accounts separately, the former account refers the capital transfer and the sale of non-productive assets. China's capital account has not yet fully liberalized, so the sum of foreign-related is small; the latter, namely financial accounts include direct investment, securities investment and other investments.

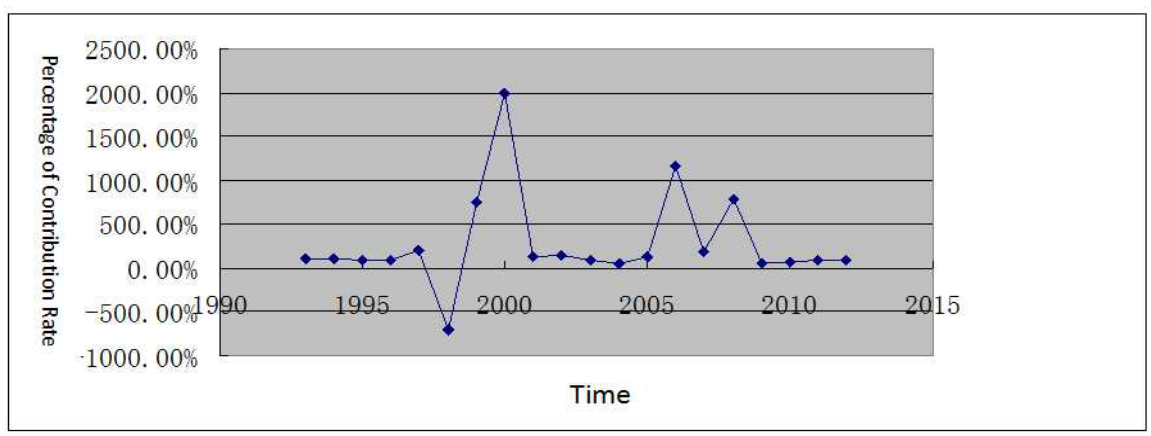

Figure 2. Contribution Rate of FDI to China's Capital and Financial Surplus from 1993-2012. 
China's securities investment and other investment have no obvious regularity, positive and negative appears alternately, and the amount is small. Only the direct investment account maintains a long-term surplus. For nearly two decades, foreign investment in China is far greater than China's foreign direct investment. It can be said that China's capital and financial surplus is mainly derived from FDI, this fact is determined simultaneously by China's national conditions, the economic policy of opening to the outside world and the changing trend of world economic pattern.

\section{Domestic Influence of China's International Balance of Payments Surplus}

Representative view of domestic scholars think the "double surplus" structure is of great significance in strengthening China's overall strength and resisting the shock of external adverse factors. Sustained double surplus of international balance of payments can increase China's foreign exchange reserves, with which China's overall strength can be enhanced, so that China has enough foreign exchange to meet international trade requirements, resist foreign debt risk and secure a favorable position within the pattern of economic globalization. When financing in the international market, big foreign exchange reserve can help to obtain various kinds of loans at lower costs, it is conductive to dealing with international financial risks and improving national economic security, which also explains why the double surplus of China's balance of payments continues for so many years. But above surplus is not sustainable in the long run, and the cost of accumulating international reserves is really high, which is unfavorable for the healthy development of China's long-term economy. Among China's four major economic control objectives, namely promoting economic growth, increasing employment, stabilizing prices and maintaining balance of payments, the last one has become the most prominent issue of macroeconomic regulation and control. In general, the continued double surplus in China arouses a series of problems. It brings excessive domestic liquidity, and then pushes up asset prices, so the central bank has to delivery of a large number of base money. As pointed out by the party's 18th CPC National Congress, the country is aimed at accelerating the transformation of foreign economic development, comprehensively improving the level of open economy, and further improving the international balance of payments. As a result of external economic imbalances, the current and future adverse effects of the long-term double surplus of China's economy are mainly reflected in the following aspects.

\subsection{Double Surplus Induces China's Inflation, Weakens the Independence of Monetary Control of the Central Bank (The People's Bank of China)}

The double surplus is the most important source of China's current excess liquidity. The double surplus of international balance of payments leads to the excessive growth of foreign exchange reserves. Under the current system of for- 
eign exchange settlement and sales in China, foreign exchange is only to be bought from the central bank. Therefore, in order to maintain the stability of the exchange rate, the central bank passively put a lot of base money in the market. We use Stata 13.1 to figure out the correlation between foreign exchange stock and base currency stock in terms of the date in last decade from the central bank, it shows that the correlation coefficient between them is as high as 0.98 . Such a high relation suggests base money related to foreign exchange has become the main channel for central bank's base currency. The increase in the base money will lead to multiple expansion of money supply. So in order to effectively control the money supply and ease the pressure on the large amount of money generated by the base currency, the central bank must take hedging operations, withdrawing money from commercial banks to rush off too much liquidity. But in doing so, the government will caught in a dilemma of maintaining exchange rate stability and reducing inflation.

In addition, the huge amount double surplus of balance of payments, by way of settlement of exchange, converses into RMB capital, and then goes into commercial banks. Funds outstanding for foreign exchange as base currency launch in market will cause multiple money supply expansions and the rapid improvement of market liquidity via money multiplier mechanism. As the scale of deposits and loans of commercial banks gradually widening, money market liquidity and other issues began to appear. In the case of capital adequacy, commercial banks may generate credit impulses, and the focus on the use efficiency of funds may be far less concerned compared with the size of the loan. When banks do not pay attention to the use efficiency of capital but grant a large number of loans, it ultimately may lead to the increase in bad or dead debts and the decline in operating capacity for the bank.

In recent years, with the rapid expansion of the foreign exchange reserves owing to the increasing expansion of the double surplus, the gap between foreign exchange increment and monetary base increment is getting bigger and bigger, which make it harder, more complex and costly for the central bank's hedging operations. Such being the situation, foreign exchange increase by a large margin caused by double surplus poses great challenge to the central bank in aspect of effectiveness and independence of its monetary policy. If China's balance of payments double surplus continues to maintain and expand, monetary policy will weigh more on hedging off too much liquidity.

\subsection{Double Surplus Increases the Appreciation Pressure of CNY and Intensifies Foreign Trade Friction}

The spot exchange rate of CNY is determined by the supply and demand in foreign exchange market. The huge foreign exchange reserves caused by the double surplus of the balance of payments have caused China to lose the dominance of monetary policy operation to a considerable extent. If it wants to reduce the influence of increased base currency caused by foreign exchange on the domestic money market, the central bank must increase the intensity of cash withdrawal 
or elevate the currency interest rate, which will bring great pressure on the appreciation of $\mathrm{CNY}$, and China will also fall into the dilemma of appreciation pressure and money supply increase. Since 2003, the international community, especially the United States, Japan and other developed countries, repeatedly claim CNY should appreciate.

The imbalance of international balance of payments is not to last for a long time. In China, continued surplus of balance of payments brings pressure from both internal and external aspects. With the big surplus of China's international balance of payments and the deficit between some major trading partners, trade frictions are intensifying among them. The long-term surplus of China's international balance of payments has become the target of trade protectionism's attacks. To the best of my knowledge, China has become the country with the most trade frictions for 17 consecutive years. The double surplus leaves a great negative impact on China's foreign trade.

\subsection{Crowding-out Effect Causes by Double Surplus Limits the Development of China's Domestic Economy}

For a long time, China adheres to export-oriented trade policy and makes favorable policies to attract foreign investment. Even if faced with limited resources, the government always gives export-oriented enterprises many preferential policies than inward-oriented enterprises. So after the allocation of resources, inward-oriented enterprises are left with limited chance and room for development, which in turn affects the expansion of China's domestic demand. By analyzing foreign investment data in past decade, the total investment of China will increase by only 0.75 units for every additional unit of FDI, which also indicates FDI has a crowding-out effect on China's domestic investment. FDI has squeezed out nearly $25 \%$ of China's domestic investment. If the circumstance continues, it may lead to the structural imbalance of the economic growth in China for a long time, which is not conducive to realize economy shift towards domestic demand led pattern.

\subsection{High Foreign Exchange Reserves Brought by Double Surplus is Shrinking and Welfare Losses is Increasing}

"Double surplus" embedded China with a huge foreign exchange reserves, which exceeded 1 trillion US dollars in 2006, and reached 3.12 trillion US dollars by the end of 2011, composing a quarter of the world's total foreign exchange reserves. But there is few effective investment outlets for China's huge foreign exchange reserves, so currently they are mainly spent on the purchase of US debt. As pointed out by the famous economist Rudi Dornbush, "for a poor country, it is not advisable to put the resource into the purchase of US treasury bills instead of making domestic investment to increase productivity and living standards." China is, in fact, introducing foreign investment at a high price while spending the accumulated foreign exchange reserves on the purchase of low-yield foreign debt assets. As the economic crisis of 2008 persisting, the United States has car- 
ried out four rounds of quantitative easing policy. So for the US Treasury bonds China bought with huge foreign exchange reserves, the opportunity cost is surplus multiplied by the domestic investment profit margins and the return of current account surplus is the surplus multiplied by the US Treasury yield. After the fourth round of quantitative easing (QE4), the US Treasury market interest rate has dropped to a very low level, making profit yielded much lower than domestic investment profit margins in China. Consequently, as surplus continues currently in China, it suggests a substantial reduction in national welfare.

\section{Policy Recommendations for China's Double Surplus}

Conclusion can be drawn from the above study that China's double surplus mainly attributes to huge absorption of FDI, and it is structural and hard to be altered in the short run. According to conventional wisdom of international balance of payments, there are two crucial policies including expenditurechanging policy and expenditure-switching policy. The former is to adjust the trade balance by acting on the total expenditure or aggregate demand, thereby affecting the demand for import and export. Expenditure-changing policy mainly includes monetary policy and fiscal policy, that is, through implementing tight monetary policy (raising interest rates or reducing the money supply) together with tight fiscal policy (raising the tax rate or reducing government spending) to lower total social demand, which in turn reducing the import demand, price levels and export costs, eventually increasing exports to realize trade balance. Whereas expenditure-switching policy is to adjust the direction of expenditure depending on economic policies such as trade policy, exchange rate policy and capital control policy, which avail to improve the current account balance or trade balance. Exchange rate policy mostly used for many developed countries can achieve the improvement of trade balance by way of currency appreciation or depreciation, while for the trade policy, it mainly rests on tariffs, non-tariff barriers, dumping, etc. In the event of a serious deficit of balance of payments, only the implementation of trade control and capital control policies can be pursued to directly influence the balance of payments in general.

Obviously, traditional balance of payments policies deal primarily with disequilibrium of balance of payments, especially when the deficit happens, and the mainstream theory focus on how to correct or reduce the extent of the deficit when a trade deficit exists in current account or trade in goods account. This is not consistent with China's double surplus structure in balance of payments, and with the forecast discussed before, this kind of phenomenon is calling for more targeted measures and policies.

In the short run, foreign investors will continue to increase investment in China's profits on account of their optimistic expectations about China's economic, but this trend could not last. Therefore, China needs to further improve the investment environment and investment strategy, and continue to attract and maintain foreign stock. Currently, most foreign direct investment is in the early stage, during which profit margin is comparatively low in the short term, 
but with the gradual progress of the investment cycle, foreign investors will finally request to export investment profits from China, and the recovery of investment costs, investment income will sooner or later be remitted. Thus, on the one hand, China needs to maintain the scale of FDI and gradually reduce dependence on it; on the other hand, it should change the structure of FDI by introducing more technology-oriented FDI, and gradually cutting down marketoriented and export-oriented FDI. At the same time, China should step by step increase its total amount of foreign investment and retake the profits of foreign investment. The report of the 18th National Congress of the Communist Party of China (CPC) pointed out that China should accelerate the transformation of foreign economic development mode, comprehensively improve the level of open economy and further improve the balance of payments by means of weighing on import and export simultaneously, combining policies of "bringing in" and "going out" (introduce foreign capital and encourage Chinese companies to invest overseas), pushing forward the marketization reform of RMB exchange rate, and strengthening cross-border capital flow regulation preventing international financial risks. The main content of China's balance of payments policy for the next stage is the formulation and implementation of foreign investment strategies and policies. China is to open two-way securities investment orderly and progressively, adjust the absorption and use policy of foreign direct investment, keep foreign reserves stable or growing at a low rate, continue to maintain the current account surplus, appropriately releasing domestic funds to invest overseas for the formation of capital and financial projects surplus.

In the long run, China should realize the transformation of economy growth mode and change the existing unreasonable circumstance that is heavily dependent on foreign investment. Since FDI is not sustainable, whether the profits can gain from FDI or not may poses potential crisis to China's economy, and there is a fair chance of massive withdrawals for those FDI enterprises. In view of these problems, it is necessary to adjust the types of FDI, regulate the retention of FDI profits, and strengthen the financial management and price regulation of foreign-funded enterprises. As China's transformation of growth mode from extensive to intensive, it will gradually reach the level of medium developed countries and realize industrialization, foreign investment policy should be adjusted accordingly. Firstly, China should pay more attention to the quality of investment, introduce more FDI to modern agriculture, service industry and high-tech industry; secondly, it should attract more FDI to non-invested regions like central and western regions; thirdly, it should develop actively outward foreign direct investment. Specifically, the government needs to stimulate domestic enterprises to extend their value chain by virtue of establishing $\mathrm{R} \& \mathrm{D}$ and marketing departments in developed countries and buying raw materials and transferring production lines in developing countries, thus reducing the costs and improving product competitiveness in the international market, which might be helpful for China to foster large multinational companies. 


\section{References}

[1] Baran, P.A. (1973) The Political Economy of Growth. Modern Reader Paperbacks, New York, 105-113.

[2] Samuelson, P. and Hass, N. (1982) The Economics. 10th Edition, The Commercial Press, Shanghai, 35-36.

[3] Dooley, M.P., Fernandez-Arias, E. and Kletzer, K.M. (1994) Recent Private Capital Inflows to Developing Countries: Is the Debt Crisis History? World Bank Economic Review, 10, 27-50. https://doi.org/10.1093/wber/10.1.27

[4] Reis, A.B. (2001) On the Welfare Effects of Foreign Investment. Journal of International Economics, 54, 411-427. https://doi.org/10.1016/S0022-1996(00)00100-8

[5] Yang, L.Y. (2003) Research on the Structure of the Balance of Payments: Theoretical Model, International Comparison and Analysis of China's Reality. China Financial Publishing House, Beijing.

[6] Liu, Z.L. (2005) FDI and China's Balance of Payments Research: Negative Effects and Prospects. Contemporary Finance and Economics, 5, 98-102.

[7] Yu, Y.D. and Tan, D.H. (2006) China's Double Surplus: Nature, Roots and Solutions. World Economy, 3, 31-41.

[8] Liu, H.Z. (2001) China's FDI: Empirical Research and Worldwide Comparison. Fudan University Press, Shanghai, 89-94.

[9] Xin, Z. (2006) China's Balance of Payments Structure: An Analysis Based on Foreign Capital Inflow. China Financial Publishing House, Beijing.

\section{Scientific Research Publishing}

Submit or recommend next manuscript to SCIRP and we will provide best service for you:

Accepting pre-submission inquiries through Email, Facebook, LinkedIn, Twitter, etc. A wide selection of journals (inclusive of 9 subjects, more than 200 journals)

Providing 24-hour high-quality service

User-friendly online submission system

Fair and swift peer-review system

Efficient typesetting and proofreading procedure

Display of the result of downloads and visits, as well as the number of cited articles

Maximum dissemination of your research work

Submit your manuscript at: http://papersubmission.scirp.org/

Or contact jss@scirp.org 